\title{
Viability Of Community Banks In The Dallas Federal Reserve District: Evidence Of Relationship And Transactional Orientation
}

John Martinez, (Email: john.martinez@mwsu.edu), Midwestern State University Roy R. Patin, Jr., (Email: roy.patin@mwsu.edu), Midwestern State University Douglas W. McNiel, (Email: dmcniel@mcneese.edu), McNeese State University

\begin{abstract}
This paper examines the viability of community banks. The results indicate that larger community banks are more profitable and less susceptible to most forms of risk than smaller community banks. Evidence that smaller community banks are more relationship oriented and larger community banks are more transactional oriented is mixed. Smaller community banks have a lower cost of funding assets, perhaps as a result of a stronger relationship with depositors, but there is no evidence that their relationship with borrowers allows them to earn more interest income. The primary indication of a stronger transactional orientation by larger community banks is their ability to generate more non-interest income.
\end{abstract}

\section{INTRODUCTION}

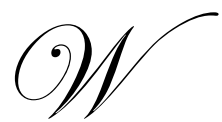

hile larger banks typically operate in regional or national markets, community banks generally restrict their activities within more narrowly defined geographic limits. It is critically important to understand whether community banks will be able to survive recent trends brought on by banking industry consolidation. This is a public policy concern because community banks are often associated with small business lending and local community development. Erosion of the viability of community banks could potentially reduce the availability of credit to small businesses or result in rising fees imposed on consumers. ${ }^{1}$ The purpose of this paper is to examine the viability of community banks, and to compare the behavior of different size community banks to discern evidence of differing managerial strategies and performance that may be relevant to their survival.

\section{COMMUNITY BANKS-DISTINGUISHING CHARACTERISTICS}

Community banks are generally categorized in the literature as institutions with less than $\$ 1$ billion in assets. They are generally perceived to be smaller institutions because of their narrower geographic and product focus in comparison to larger banks which tend to operate on a regional or national scale offering a broader range of products and services. In the year 2004 there were 730 "community banks" with assets less than $\$ 1$ billion and just 31 larger banks with assets in excess of $\$ 1$ billion operating in the Dallas Federal Reserve District. While far more numerous, the community banks held only $44 \%$ of all banking assets in the Dallas FED.

The current imbalance between the distribution of banking establishments and banking assets can be attributed to a number of factors. Most important of these factors are consolidations resulting from sweeping legislative changes ${ }^{2}$ which led to widespread geographic and product deregulation, and extraordinary technological transformations ${ }^{3}$ in the banking industry over the last 20 years. 
Several arguments support the notion that community banks cannot adequately compete with larger banking organizations. Small size may prevent management from investing sufficient amounts in new technologies to compete more effectively. Berger (2003) discusses a number of factors that may prevent smaller banks from adequately diversifying credit risk and thereby making long-term success less likely. ${ }^{4}$ Another argument relates to the essential function of an intermediary in gathering, collecting, analyzing, and disseminating the information necessary to facilitate the flow of funds from lenders to borrowers. While dramatic advances in technology have made gathering and analyzing information less costly, thereby reducing the value of the intermediary function, ${ }^{5}$ the prevailing sentiment in the literature generally assumes that larger organizations have a comparative advantage in accessing valuable information for facilitating transactions. Finally, there is the argument that smaller banks are unable to take advantage of economies of scale that enable larger banks to reduce costs of providing services.

If the arguments listed above are valid, further industry consolidation would seem to be an inevitable trend. There is, however, also evidence of countervailing community bank trends. Continued entry of de novo banks into the industry ${ }^{6}$ and continued growth of existing small community banks (Bassett and Brady 2001) suggests that there may be reasons why community banks will continue to survive and prosper. Recent academic research provides conflicting evidence on whether or not significant cost differentials exist for larger and more diversified banks (Berger and Humphrey 1999). As a result, there is no consensus about what size of bank, or what banking organizational structure, provides the greatest efficiency.

\section{Differences In Strategic Managerial Orientation}

Community banks are generally portrayed or modeled in the literature as homogeneous financial intermediaries in comparisons with larger commercial banks. But that perspective may mislead and mask important differences among community banks that affect their long-term viability.

Sharpe (1990), Diamond (1991), and Rajan (1992) emphasize that not all financial intermediaries collect and analyze information in the same way. They argue that differences in strategic managerial orientation, such as a relationship banking orientation or a transactional banking orientation, may provide banks with distinct comparative cost advantages and explain important differences in behavior and performance that affect their viability. Relationship banking is generally associated with smaller banks and transactional banking is typically associated with larger banking entities.

\section{Relationship Banking Orientation}

Relationship oriented bank managers place greater emphasis on long-term customer relationships and providing personal banking service to customers. A relationship banking orientation involves the use of personal oneon-one understanding and knowledge between the parties.

On the lending side, relationship banking places emphasis on human-aided transactions. In making lending decisions, bank employees develop and exploit so-called "soft" information ${ }^{7}$ that is not readily available or easily quantifiable. Soft information requires more human discretion and evaluation and is acquired primarily by working in close contact with the banking customer. Relationship-oriented borrowers value the intimate knowledge their banker has of their personal situation. They prefer to deal consistently with the same individuals whom they do not have to frequently re-educate about their own unique financial and business situation. Such customers may be willing to pay relatively higher rates for loans, or the same rate with a reduced level of ancillary service.

In many smaller companies, financial statements are not standardized and management may lack the financial expertise needed to participate in financial transactions. Lenders to these companies need to evaluate "soft" information in making a credit decision to such customers. The lender may also add real value by providing accounting, business planning, and tax planning expertise - cross-selling noncredit products and services in order to lock in or enhance the relationship. ${ }^{8}$ The familiarity between borrower and lender facilitates long term transactions, negating the need to begin the information search anew every time a loan is extended. These services generally require localized decision making. In attempting to exploit information that is difficult to assess and evaluate, the loan 
officer must be given the latitude and ability to act on this information without the approval of those further removed from the situation. Relationship lending thus provides a niche for community institutions that many large banks find less attractive or are less capable of filling - see Berger and Udell (1995, 2002) and Scott and Dunkelberg (2004).

Berger and Udell (2002) argue that banks offering relationship lending must delegate more lending authority to their loan officers than do banks that focus on transactional lending. They also contend that small community banks are better able to resolve problems associated with delegating authority than large banks, meaning they should be better equipped to engage in relationship lending than large banks.

Most small bank stock is privately held rather than publicly traded while large bank stock is generally publicly traded. That means the ownership of small banks is more concentrated in the hands of fewer stockholders whereas ownership of large banks is more widely dispersed. At small banks where ownership is more concentrated, owners are more actively involved in managing the banks. For example, Brickley, Linck, and Smith (2003) show that small bank ownership in Texas is much more concentrated than it is for large banks. Officers and directors of small banks owned roughly two-thirds of their banks' stock while the officers and directors of the large banks in their sample owned only about one-quarter of the stock.

The fact that local decision makers in small banks own relatively more stock in the banks and are more actively involved in the banks' management mitigates agency problems. Brickley, Linck, and Smith (2003) argue that this setup allows smaller banks to grant local managers more decision authority. Allowing the person who acquires soft information on a borrower to act upon the information makes it easier for smaller banks to engage in relationship lending. This line of reasoning is similar to that of Berger and Udell (2002), who argue that stockholders in large banks, who are more dispersed and not local, are less willing to grant decision-making authority to local managers and prefer instead to use more bureaucratic rules for decision making.

\section{Transactional Banking Orientation}

Transactional banking is oriented toward the provision of intermediation services on the basis of more formulaic, impersonal rules. Because these transactional products are generally highly standardized, easily available, and reliable, they require little human discretion in their provision.

For transactional banking, hard information drives the intermediation process. Frame, Srinivasan, and Woosley (2001) provide evidence that large banks increasingly use the process of incorporating hard information into quantitative decision-making models for credit scoring purposes. Based on this so-called hard information, the results from such models are then used to make decisions regarding business loans. This credit scoring process is more mechanical in that it involves less human input, thereby eliminating the need for more personalized input from local loan officers.

To the extent that loans to small businesses, agriculture customers, and individuals can be successfully credit scored over time, relationship oriented banks will face increasing competition in their loan portfolios from transactional oriented banks. However, the use of credit scoring systems generally does not allow the provision of real value from the banker, as described above.

With credit approval from analysts far removed from the borrower and decision making concentrated among fewer entities, large banks can offer more attractive rates to their most profitable customers. Less profitable customers may receive the same stated rate, but are often given access to a reduced level of service thus ultimately paying higher real fees and rates. Yet many customers do not need or want a broad array of credit, deposit, insurance, and trust services from their bank.

The typical bank engages in both types of lending — transactional and relationship. Though the two types are not necessarily substitutes for each other, larger banks are more likely to adhere to a transactional approach in their operations while smaller banks would be more inclined to focus on relationship banking. Transactional banking is generally associated with economies of scale because unit costs fall with increasing bank size. The section that 
follows examines the question of whether smaller community banks operate differently from larger community banks and whether these differences can be linked to a relationship or transactional orientation.

\section{Data and Methodology}

Others have focused on differences between community banks and large banking organizations. ${ }^{9}$ We seek to discern whether there are important distinctions between smaller and larger community banks.

The data set compiled by the Federal Deposit Insurance Corporation includes all 761 FDIC insured commercial banks and thrifts operating in the Dallas Federal Reserve District in 2004. Since the general demarcation in the literature for identifying community banks is those institutions with less than $\$ 1$ billion in assets, the analysis that follows focuses on the 730 institutions in the FDIC database below that asset size limit.

For the 730 community banks in the sample, the median asset size was $\$ 80$ million. This breakpoint was used to divide the sample into two comparison groups of community banks. The 365 banks with assets less than $\$ 80$ million are categorized as "smaller community banks". The 365 banks with assets greater than $\$ 80$ million, but less than $\$ 1$ billion, are categorized as "larger community banks".

To gain insight regarding the viability of community banks and possible differences in strategic managerial orientation between the smaller and larger community banks, traditional t-test procedures are used to analyze differences in operating characteristics across the two different size categories. We examine whether characteristics indicative of relationship banking are associated with the sample of smaller community banks and whether characteristics indicative of transactional banking are associated with the sample of larger community banks.

\section{STATISTICAL RESULTS}

Results of statistical tests for differences in the characteristics and performance of the comparison groups of smaller and larger community banks are shown in Table 1 . The mean asset size is nearly $\$ 46$ million for the smallest 365 community banks in the sample, and almost $\$ 226$ million for the largest 365 community banks in the sample.

\section{Average Expense Ratios}

The expenses of banking institutions may be divided into to broad categories-interest expense and noninterest expense. Both are compared in the table as a share of earning assets for the two groups of community banks.

The ratio of interest expense to earning assets is the annualized total interest expense paid on deposits and other borrowed money as a percent of average earning assets on a consolidated basis. This ratio can also be viewed as the "cost of funding assets". Interest expense (cost of funding loan assets) is lower for the smaller community banks than for the larger community banks. This result might be expected if smaller community banks are able to induce depositors to accept lower interest rates on their deposits as a result of a relationship banking strategy. Larger community banks with a more transactional orientation must pay higher interest rates to attract deposits from customers with which they have a weaker personal relationship.

The ratio of non-interest expense to earning assets is the total cost of salaries and employee benefits, expenses of premises and fixed assets, and other non-interest expenses (annualized) as a percent of average earning assets. No significant differences in non-interest expenses were found when comparing the samples of smaller and larger community banks. This result suggests that, on average, the group of larger community banks was unable to achieve economies of scale (lower non-interest costs) if they were indeed adopting a more transactional banking orientation.

The assets per employee ratio measures total assets in millions of dollars as a percent of the number of fulltime equivalent employees. The reciprocal of this ratio suggests that smaller community banks appear to have higher labor input requirements than larger community banks. This is consistent with a more labor-intensive relationship 
banking orientation by smaller community banks and a less labor-intensive transactional orientation by larger community banks.

\section{Average Income Ratios}

The income of banking institutions can also be divided into two broad categories - interest income and noninterest income. Both are compared as a share of earning assets for the two groups of community banks.

The ratio of interest income to earning assets is the total interest income (annualized) as a percent of average earning assets. It can also be viewed as the yield on assets. There is no significant difference between the two groups of community banks in the interest income (yield on assets). This suggests that, on average, the explicit or nominal interest rate charged on loans does not differ significantly for smaller and larger community banks. If smaller community banks are more relationship oriented, there is no evidence that it enables them to charge higher nominal loan rates.

The ratio of non-interest income to earning assets is income derived from bank services and sources other than interest bearing assets (annualized) as a percent of average earning assets. Larger community banks earn more non-interest income than smaller community banks. This is consistent with a transactional orientation by larger community banks leading to greater reliance on fee income. ${ }^{10}$

\section{Efficiency Ratio}

The efficiency ratio reported in the table measures non-interest expense, less the amortization expense of intangible assets, as a percent of the sum of net interest income and non-interest income. It indicates that on average, larger community banks are more efficient than smaller community banks. From the results reported above, it appears this outcome results from larger community banks generating more non-interest income than smaller community banks.

\section{Profitability Ratios}

Comparisons of five profitability ratios are shown in the table. These ratios are defined as follows:

- $\quad$ Net Operating Income to Assets $=$ Net operating income (annualized) as a percent of average assets.

- $\quad$ Return on Assets = Net income after taxes and extraordinary items (annualized) as a percent of average total assets.

- $\quad$ Pretax Return on Assets = Annualized pre-tax net income as a percent of average assets. (Includes extraordinary items and other adjustments net of taxes.)

- $\quad$ Return on Equity $(R O E)=$ Annualized net income as a percent of average equity on a consolidated basis. (If retained earnings are negative, the ratio is treated as not available.)

- $\quad$ Retained Earnings to Average Equity = Net income (year-to-date, annualized), as a percent of average total equity capital. (If retained earnings are negative, the ratio is treated as not available.)

All profitability comparisons indicate that larger community banks are more profitable than smaller community banks. 
Table 1

Differences In Selected Mean Ratios For Small And Large Community Banks In The Dallas Federal Reserve District, 2004.

\begin{tabular}{|c|c|c|c|c|}
\hline $\begin{array}{c}\text { Variable } \\
\text { Description }\end{array}$ & $\begin{array}{c}\text { Smaller } \\
\text { Community } \\
\text { Banks* }\end{array}$ & $\begin{array}{l}\text { Larger } \\
\text { Community } \\
\text { Banks** }\end{array}$ & t-Value & $P>|t|$ \\
\hline $\begin{array}{c}\text { Number of Community Banks } \\
\text { Average Total Assets (\$ millions) }\end{array}$ & $\begin{array}{c}365 \\
\$ 45.609\end{array}$ & $\begin{array}{c}365 \\
\$ 225.885\end{array}$ & -18.48 & 0.0000 \\
\hline $\begin{array}{c}\text { Average Expense Ratios: } \\
\text { Interest Expense to Earning Assets } \\
\text { Non-interest Expense to Earning Assets } \\
\text { Assets per Employee (\$ millions) }\end{array}$ & $\begin{array}{c}0.0112 \\
0.0395 \\
2.722\end{array}$ & $\begin{array}{c}0.0128 \\
0.0395 \\
3.127\end{array}$ & $\begin{array}{l}-3.79 \\
0.01 \\
-2.99\end{array}$ & $\begin{array}{l}0.0002 \\
0.9901 \\
0.0029\end{array}$ \\
\hline $\begin{array}{l}\text { Average Income Ratios: } \\
\text { Interest Income to Earning Assets } \\
\text { Non-interest Income to Earning Assets } \\
\text { Non-operating Income to Assets }\end{array}$ & $\begin{array}{l}0.0541 \\
0.0104 \\
0.0009\end{array}$ & $\begin{array}{l}0.0552 \\
0.0158 \\
0.0012\end{array}$ & $\begin{array}{l}-1.34 \\
-1.95 \\
-3.34\end{array}$ & $\begin{array}{l}0.1796 \\
0.0510 \\
0.0009\end{array}$ \\
\hline Average Efficiency Ratio: & 0.7738 & 0.6572 & 4.48 & 0.0000 \\
\hline $\begin{array}{c}\text { Average Profitability Ratios: } \\
\text { Net Operating Income to Assets } \\
\text { Return on Assets } \\
\text { Pretax Return on Assets } \\
\text { Return on Equity (ROE) } \\
\text { Retained Earnings to Average Equity }\end{array}$ & $\begin{array}{l}0.0088 \\
0.0090 \\
0.0104 \\
0.0887 \\
0.0287\end{array}$ & $\begin{array}{l}0.0121 \\
0.0123 \\
0.0153 \\
0.1319 \\
0.0585\end{array}$ & $\begin{array}{l}-4.71 \\
-4.65 \\
-6.11 \\
-5.78 \\
-3.97\end{array}$ & $\begin{array}{l}0.0000 \\
0.0000 \\
0.0000 \\
0.0000 \\
0.0000\end{array}$ \\
\hline $\begin{array}{c}\text { Average Risk Ratios: } \\
\text { Noncurrent Loans to Loans } \\
\text { Noncurrent Assets Plus Other Real Estate Owned to Assets } \\
\text { Loss Allowance to Loans } \\
\text { Net Charge-offs to Loans } \\
\text { Volatile Liabilities to Assets }\end{array}$ & $\begin{array}{l}0.0119 \\
0.0079 \\
0.0165 \\
0.0039 \\
0.1615\end{array}$ & $\begin{array}{l}0.0069 \\
0.0054 \\
0.0121 \\
0.0024 \\
0.1954\end{array}$ & $\begin{array}{c}5.10 \\
3.58 \\
6.88 \\
2.40 \\
-3.23\end{array}$ & $\begin{array}{l}0.0000 \\
0.0004 \\
0.0000 \\
0.0167 \\
0.0013\end{array}$ \\
\hline
\end{tabular}

\section{Risk Ratios}

Five measures of credit risk are compared in the table. These measures are defined as follows:

- $\quad$ Noncurrent Loans to Loans $=$ Loans and leases 90 days or more past due plus loans in nonaccrual status, as a percent of gross loans and leases.

- $\quad$ Noncurrent Assets Plus Other Real Estate Owned to Assets: Noncurrent assets are defined as assets that are past due 90 days or more plus assets placed in nonaccrual status plus other real estate owned (excluding direct and indirect investments in real estate).

- Loss Allowance to Loans = Allowance for loan and lease losses as a percent of total loan and lease financing receivables, excluding unearned income.

- Net Charge-offs to Loans = Gross loan and lease financing receivable charge-offs, less gross recoveries, (annualized) as a percent of average total loans and lease financing receivables. 
- $\quad$ Volatile Liabilities to Assets $=$ The sum of large-denomination time deposits, foreign-office deposits, federal funds purchased, securities sold under agreements to repurchase, and other borrowings. Trading liabilities, less revaluation losses on assets held in trading accounts are included.

The credit risk measures suggest that the risk from loan default and noncurrent assets is greater for the smaller community banks than the larger community banks. Risk from volatile liabilities is greater at larger community banks.

\section{SUMMARY AND CONCLUSIONS}

It appears that larger community banks are more economically viable than smaller community banks. The larger community banks are more profitable and less susceptible to most forms of risk than smaller community banks.

Evidence that smaller community banks are more relationship oriented is mixed. Smaller community banks have a lower cost of funding assets (lower interest expense), perhaps as a result of a stronger relationship with depositors. However, there is no evidence that their relationship with borrowers allows them to charge higher loan rates (earn more interest income). The primary evidence of a stronger transactional orientation by larger community banks is their ability to generate more non-interest income.

\section{SUGGESTIONS FOR FURTHER RESEARCH}

Future research focusing on identifying more empirically measurable characteristics for distinguishing relationship and transactional orientation among banking institutions could help further clarify issues examined in this paper. The geographic scope of this paper was limited to one particular region of the country. Expanding the scope on a national basis would enhance the generality of the paper's findings.

\section{ENDNOTES}

1. Federal Reserve Bank surveys consistently show that large banking organizations charge higher fees than community banks - see Hannan (2002) and Berger and Udell (2002). Scott and Dunkelberg (2004) provide evidence that credit service for small business firms is better at community banks than at large banks.

2. The Interstate Banking and Branching Efficiency (Riegle-Neal) Act of 1994 resulted in the elimination of restrictions against interstate and intrastate banking. The Financial Services Modernization (Gramm-Leach-Bliley) Act in 1999 resulted in more product deregulation.

3. Berger and Mester (2003) and Allen, McAndrews, and Strahan (2002) provide discussions on technological change and banking.

4. Yeager (2004) provides evidence that the geographic concentration risk that community banks must bear is not responsible for the declining numbers of community banks in the United States.

5. Petersen and Rajan (2002), for example, provide evidence that small businesses are now better able to borrow from more physically distant lenders than they were in the past.

6. DeYoung and Hasan (1998) and DeYoung (1999) discuss and present evidence on de novo banks.

7. Information can be differentiated as being "hard" or "soft". Hard information consists of easily verifiable facts that can be credibly shared. Soft information consists of the personal opinions of an individual evaluator who knows the person whose information is being evaluated. Many argue that community banks are better equipped to produce soft information than are larger banks — see Berger and Udell (2002), Scott (2004), and Scott and Dunkelberg (2004).

8. DeYoung, Hunter, and Udell (2003) discuss relationship lending from the perspective of bankers having access to soft information acquired through personal contact with the borrower. While we do not disagree that this element is important to relationship banking at community banks, our definition is broader, emphasizing that the lender may be additionally providing value associated with tax, accounting, and other expertise as well as funds.

9. DeYoung (2003) provides a recent study of the viability of community banks.

10. Non-interest income includes income from fiduciary activities, service charges on deposit accounts, trading revenues, investment banking fees, venture capital revenue, servicing fees, securitization income, and insurance commissions and fees. 


\section{REFERENCES}

1. Allen, Franklin, James McAndrews, and Philip Strahan. 2002. E-Finance: An Introduction. Journal of Financial Services Research 22, nos. 1-2:5-27.

2. Bassett, William F. and Thomas Brady. 2001. The Economic Performance of Small Banks, 1985-2000. Federal Reserve Bulletin (November): 719-28.

3. Berger, Allen N. 2003. The Economic Effects of Technological Progress: Evidence from the Banking Industry. Journal of Money, Credit, and Banking 35, no. 2:141-76.

4. Berger, Allen N. and David Humphrey. 1999. Bank Scale Economies, Mergers, Concentration, and Efficiency: The U.S. Experience. University of Pennsylvania Wharton School Working Paper.

5. Berger, Allen N. and Loretta J. Mester. 2003. Explaining the Dramatic Changes in Performance of U.S. Banks: Technological Change, Deregulation, and Dynamic Changes in Competition. Journal of Financial Intermediation 12, no. 1:57-95.

6. Berger, Allen N. and Gregory F. Udell. 1995. Relationship Lending and Lines of Credit in Small Firm Finance. Journal of Business 68, no. 3:351-81.

7. Berger, Allen N. and Gregory F. Udell. 2002. Small Business Credit Availability and Relationship Lending: The Importance of Bank Organizational Structure. Economic Journal 112, no. 477:32-53.

8. Brickley, James A., James S. Linck, and Clifford W. Smith Jr. 2003. Boundaries of the Firm: Evidence from the Banking Industry. Journal of Financial Economics 70, no. 3:351-83.

9. Carter, David A., James E. McNulty, and James A. Verbrugge. 2004. Do Small Banks Have an Advantage in Lending? An Examination of Risk-Adjusted Yields on Business Loans at Large and Small Banks. Journal of Financial Services Research 25, no. 2 (2004): 233-52.

10. Clark, Jeffrey A. and Thomas F. Siems. 2002. X-efficiency in Banking: Looking Beyond the Balance Sheet. Journal of Money, Credit, and Banking 34, no. 4: 987-1013.

11. DeYoung, Robert. 1999. Birth, Growth, and Life or Death of Newly Chartered Banks. Federal Reserve Bank of Chicago Economic Perspectives 23, no. 3:18-35.

12. DeYoung, Robert. 2003. Whither the Community Bank? A Conference Summary. Chicago Fed Letter 189a, May.

13. DeYoung, Robert and Iftekhar Hasan. 1998. The Performance of De Novo Commercial Banks: A Profit Efficiency Approach. Journal of Banking and Finance 22, no. 5:565-87.

14. DeYoung, Robert, William C. Hunter, and Gregory F. Udell. 2003. The Past, Present, and Probable Future for Community Banks. Federal Reserve Bank of Chicago Working Paper No. 2003-14.

15. DeYoung, Robert and Tara Rice. 2004. Non-Interest Income and Financial Performance at U.S. Commercial Banks. Financial Review 39, no. 1:101-27.

16. Diamond, Douglas W. 1991. Monitoring and Reputation: The Choice Between Bank Loans and Directly Placed Debt. Journal of Political Economy 99, no. 4:689-721.

17. Federal Deposit Insurance Corporation (FDIC). 2002. FDIC Quarterly Banking Profile, fourth quarter.

18. Frame, W. Scott, Aruna Srinivasan, and Lynn Woosley. 2001. The Effect of Credit Scoring on Small-Business Lending. Journal of Money, Credit, and Banking 33, no.3:813-25.

19. Hannan, Timothy H. 2002. Retail Fees of Depository Institutions, 1997-2001. Federal Reserve Bulletin (September): 405-13.

20. Petersen, Mitchell A. and Raghuram G. Rajan. 2002. Does Distance Still Matter? The Information Revolution in Small Business Lending. Journal of Finance 57, no. 6:2533-70.

21. Pilloff, Steven and Stephen Rhoades. 2000. Do Large, Diversified Banking Organizations Have Competitive Advantages? Review of Industrial Organization 16, no. 3:287-302.

22. Rajan, Raghuram G. 1992. Insiders and Outsiders: The Choice Between Informed and Arm's Length Debt. Journal of Finance 47, no. 4:1367-1400.

23. Scott, Jonathan A. 2004. Small Business and the Value of Community Financial Institutions. Journal of Financial Services Research 25, no. 2:207-30.

24. Scott, Jonathan A. and William C. Dunkelberg. 2004. A Note on Small Business Banking Outcomes and Community Banks. Temple University Working Paper, September.

25. Sharpe, Steven A. 1990. Asymmetric Information, Bank Lending, and Implicit Contracts: A Stylized Model of Customer Relationships. Journal of Finance 45, no. 4:1069-87.

26. Yeager, Timothy J. 2004. The Demise of Community Banks? Local Economic Shocks Are Not to Blame. Journal of Banking and Finance 28, no. 9:2135-53. 